Potravinarstvo Slovak Journal of Food Sciences

vol. 15, 2021, p. 274-284

https://doi.org/10.5219/1562

Received: 2 February 2021. Accepted: 9 April 2021.

Available online: 28 April 2021 at www.potravinarstvo.com

(C) 2021 Potravinarstvo Slovak Journal of Food Sciences, License: CC BY 4.0

ISSN 1337-0960 (online)

\title{
BEE STIMULATION TO FORM PROTEIN FOOD RESERVES
}

\author{
Serhii Velychko, Valeryii Brovarskyi, Ján Brindza
}

\begin{abstract}
We have investigated different ways of bees' stimulation to lay protein food while using artificial honeycombs. It has been proved that the use of artificial combs to get bee-bread upon the condition of the post-treatment processing of its elements by wax and honey syrup does not stimulate bees to lay and process protein food in their cells. It has been identified that upon the condition of the direct involvement of the working bees into the formation of bee-bread supplies the protein food has been mostly consumed. This proves that the working bees use the freshly-gathered pollen pellet for their own needs in the period of its active gathering. It has been determined that the most effective way of bee stimulation to reprocess pollen pellet into bee-bread is it's single densifying in artificial honeycombs with the follow-up processing of the upper layer of the feed by honey. This way encourages bees to form stocks of bee bread and decreases their activity of consuming protein food from cells of artificial honeycombs. The processing of thickened pollen pellet by honey probably oppresses the bees' need to consume protein food from the packed cells redirecting them to other honeycombs of the bee family's nest which has areas with bee-bread reserves.
\end{abstract}

Keywords: ethnology of bees; bee-bread; artificial honeycombs; bee colonies; stimulation

\section{INTRODUCTION}

Pollen is the only source of protein that bees collect from nature. This is very important for the development of the offspring, and thus for the development of bee colonies (Anđelković et al., 2012). In one day, the bee colony can collect from 50 to $250 \mathrm{~g}$ of pollen (Komosińska-Vassev et al., 2015). Bee family can collect from 15 to $40 \mathrm{~kg}$ of pollen per year (Zuluaga, Serrato and Quicazan, 2015). The average weight of pollen carried by the bees is about $7.5 \mathrm{mg}$.

The next stage of pollen transport is the pollen being collected from the foraging bees to the hive and packed into honeycomb cells (Fuenmayor et al., 2014). Non-flying bees fill the mixture into honeycomb cells for $3 / 4$ of the cell volume (Barajas, Cortes-Rodriguez, RodríguezSandoval, 2012). When being packed into the cells, the pollen is further enriched by the bees with honey, as well as digestive enzymes and organic acids that are contained in the secretions of the salivary glands of bees (Barajas, Cortes-Rodriguez, Rodríguez-Sandoval, 2012; Deveza et al., 2015; Zuluaga, Serrato and Quicazan, 2015). The process of lactic fermentation of pollen caused by bacilli of Lactobacillus bacteria spontaneously occurs in the honeycombs, under anaerobic conditions. This type of lactic acid fermentation is similar to that in yogurts (and other fermented milk products) and renders the final product more digestible and enriched with new nutrients (Krell, 1996). The concentration of lactic acid in bee bread is six-fold higher than in pollen (Nagai et al., 2004). The processes of pollen transformation to bee bread are accompanied by biochemical reactions. It is postulated that this is the result of microorganisms' activity, particularly lactic acid bacteria (Anđelković et al., 2012). The presence of lactic acid preserves the bee bread, which, in turn, affects the ability of longer storage of the resulting product.

Pollen sheaths are dissolved just in the process of pollen transformation into the bee bread and in this form, it becomes more readily absorbed. Fermentation to the form of bee bread not only protects the pollen against the loss of properties but also gives rise to new components as a result of enzymatic transformations. The pollen proteins are degraded to peptides and amino acids during the fermentation process (Barajas, Cortes-Rodriguez and Rodríguez-Sandoval, 2012).

Proper hive management promotes the bee-bread collection, aimed at marketing it for human consumption since it can be considered as a food supplement due to its content of a wide range of nutrients. One of the contributions to their high nutritional value is the presence of significant amounts of proteins, flavonoids, vitamins, and phenolic compounds as natural antioxidants (Horčinová Sedláčková et al., 2020b; Hudz et al., 2017b; Vergun et al., 2019) The potential application of "bee bread" as a food and as a nutraceutical supplement depends in large part on its chemical composition which varies directly with the flora of the region and the time of collection by the bees (Čeksterytè et al., 2008). Bee bread differs from pollen by lower $\mathrm{pH}(3.8-4.3)$, it contains fewer proteins and fats, but more carbohydrates and lactic acid. Bee bread has a better 
bioavailability because the walls of pollen, which cannot be destructed by gastrointestinal liquids, have been partly destructed by fermentation and the functionally and energetically rich content of pollen can be assimilated and used easier (Fatrcová-Šramková, Nôžková and Ostrovský, 2010; Mizrahi and Lensky, 1997). Pollen from entomophilous plants is characterized by higher nutritional value compared to that from anemophilous ones (Anđelković et al., 2012). The study conducted by DeGrandi-Hoffman, Chen and Simonds (2013) showed that protein concentration in the pollen is higher than that in bee bread, while amino acid concentrations were lower in most cases. An elevated level of free amino acids may be the result of an activity of specific proteolytic enzymes that cause the breakdown of peptide bonds within the polypeptide chain. The concentration of certain amino acids (tryptophan) may be lower in bee bread compared to pollen. This phenomenon may be related to the reduction process, which is caused by microbial activity. Some microorganisms can use amino acids as a source of carbon and energy for their growth. Furthermore, free amino acids can also be incorporated into the structure of proteins, which, in turn, reduces their concentration. The content of these compounds in bee bread may be determined not only by the source of pollen but also by the genotype of bees performing the conversion to the bee bread (DeGrandiHoffman, Chen and Simonds, 2013; Lokutova, 2015). Bee bread has antimicrobial (Didaras et al., 2020; Urcan et al., 2018), antibacterial (Abouda et al., 2011; Baltrušaityté, Venskutonis and Čeksteryte, 2007; Nikolaieva et al., 2019), antioxidant (Bleha et al., 2019a, Bleha et al., 2019b; Hudz et al., 2017a), hepatoprotective (Yildiz et al., 2013), immuno-modulating and antiradiation activity (Breed, Mizrahi and Lensky, 1998), adaptogenic properties (Haščík et al., 2020). It stimulates protective forces of the human body, normalizes metabolism, has a positive influence on the liver, nervous and endocrine system functions (Capcarová et al., 2020), and enhances regeneration of tissues, physical and mental persistence of the human body (Bogdanov, 2015).

Results of other studies (Brindza et al., 2015; Ivanišová et al., 2015) demonstrate that bee bread is a very good source of bioactive compounds not only with antioxidant but also antimicrobial effect. The best results were observed in most of the parameters in the sample from Poltava oblast. Bee bread can be used more in the future not only in medicine, pharmacy but also in the food industry. For confirmation of biological effect is necessary more and intensive study, in vivo test for evaluating bioactive components and digestibility properties; very important is not only determining some negative compounds which can decrease the quality of bee bread (heavy metal, radionuclide, and microbes) but also evaluation of pollen sizes (Grygorieva et al., 2018; Horčinová Sedláčková, Grygorieva and Brindza, 2020a ; Motyleva, Gruner and Semenova, 2018a; Motyleva et al., 2018b) and mineral composition of pollen (Motyleva et al., 2018b). Results are an important tool for recognizing bee bread as being a beneficial source of natural nutrients (Hudz et al., 2017b; Ivanišová et al., 2015).

\section{Scientific hypothesis}

The bees use bee pollen pellets to store bee bread as a source of nutrition for the bee colony in the honeycomb cells formed. In experiments, we assumed that bees will also use artificial honeycombs for this process, to which a pollen pellet will also be supplied. Proof of the acceptance of artificial honeycombs by the bee colony will be the preparation of bee bread for its nutrition.

\section{MATERIAL AND METHODOLOGY \\ Description of the Experiment}

Taking into account the peculiarity of bees' reaction to non-natural materials for them, we have to solve two problems, namely, encourage bees to domesticate the artificial honeycomb and make them concentrate protein feed in its cells (Figure 1). To do the research, we have used several ways of attracting bees to domesticate cells. The first one dealt with the preparation of the containers themselves. Thus, to control the process we have used artificial honeycombs without any previous preparation. Having joined the details (containers, middle wall, frieze rail) we have put them into the nest of bee colonies between the feeding and brood parts. During the whole period of the investigation, we have daily examined and identified the number of cells in the containers that are filled with bee bread.

In other cases, the cells with honeycombs have been processed. In research group 1 the honeycombs have been processed by wax. To do this, the containers have been put into the melted wax for a few seconds, and then honeycombs have been formed out of them and have been put into the nests of bee colonies into the same areas of nests as in the test group. In the research group, 2 artificial honeycombs, except the ones that have been processed by wax, have been irrigated by honey syrup. Having installed honeycombs into the nests of bee colonies, the records have been done in the same way as in the test group (Brovarskyi et al., 2016).

The next type of reaction of bees on laying protein feed was encouraging them to concentrate on making bee bread pellets using attracting workers by putting pollen pellet directly into the cells of containers of the artificial honeycomb (Figure 2). We have used 4 methods in these investigations. They had one thing in common. Artificial honeycombs couldn't be processed by wax. We have manually put $3-5$ pollen pellets into their cells. The thing that made these methods different was the fact that the dry pollen pellet has been put into the cells of honeycombs (group 3), having filled up $3-4$ dried pollen pellets, the cells have been irrigated by honey syrup and their content has been trampled down using the thickener we have designed (research group 4). In group 5 freshly harvested pollen pellet has been put into the cells, in group 6 it has been additionally thickened, but it hasn't been processed by honey syrup as in research group 4 (Figure 3). 


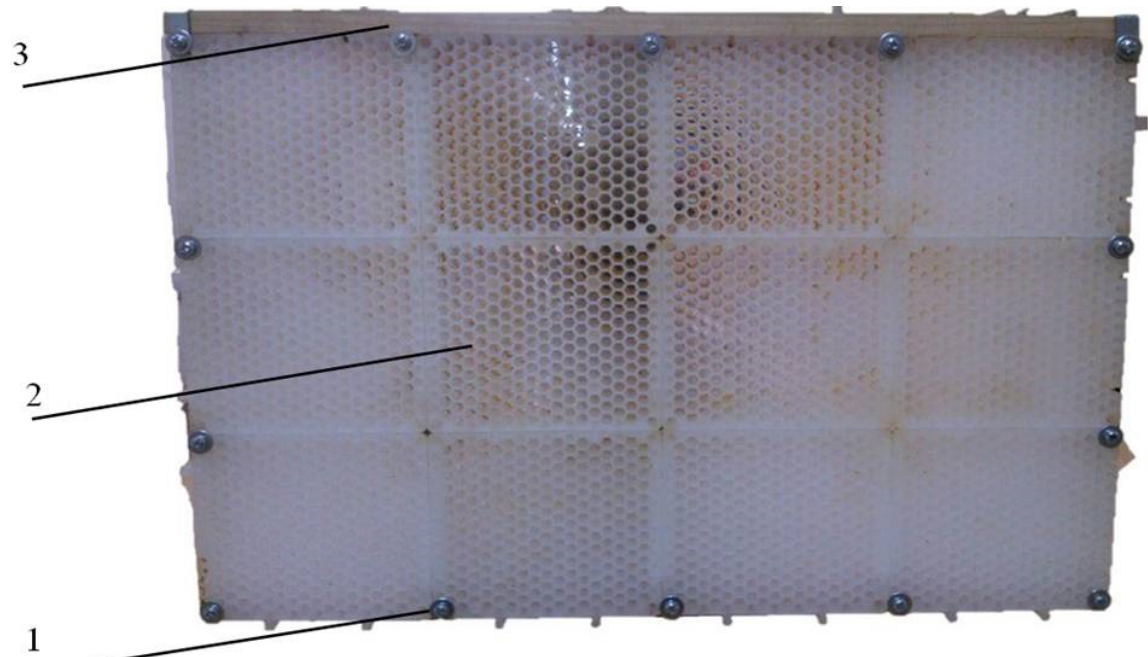

Figure 1 General view of artificial combs to get bee bread. Note: 1. Clamping 2. Artificial combs 3. Wooden block.

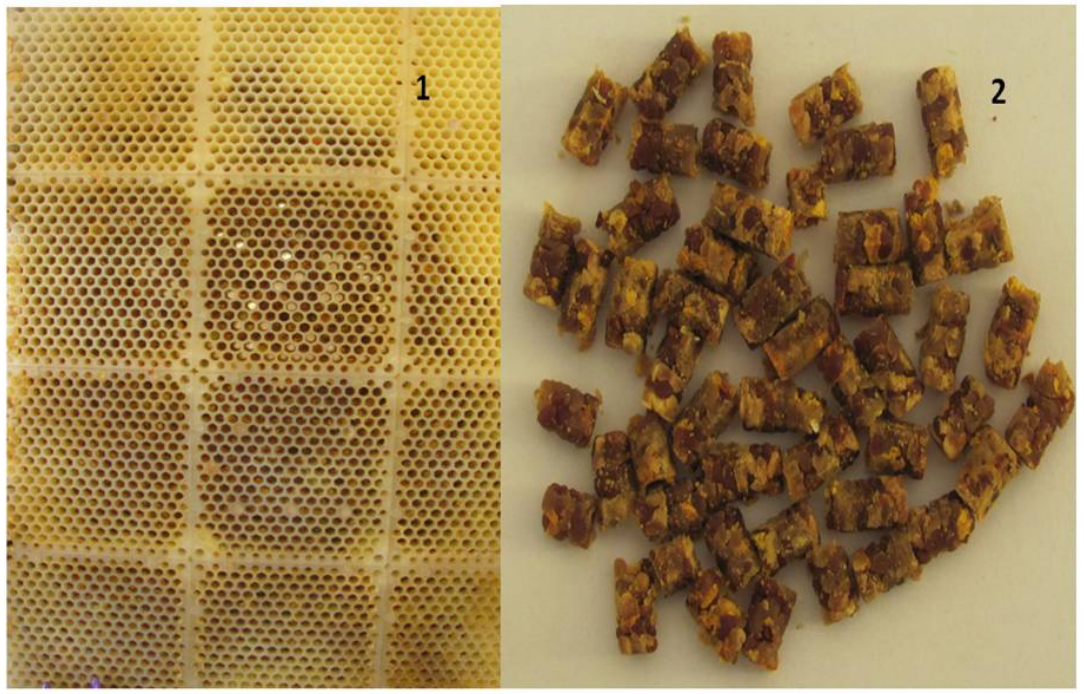

Figure 2 General view of artificial combs to get bee bread (1), bee bread pellets derived from new technology (2).

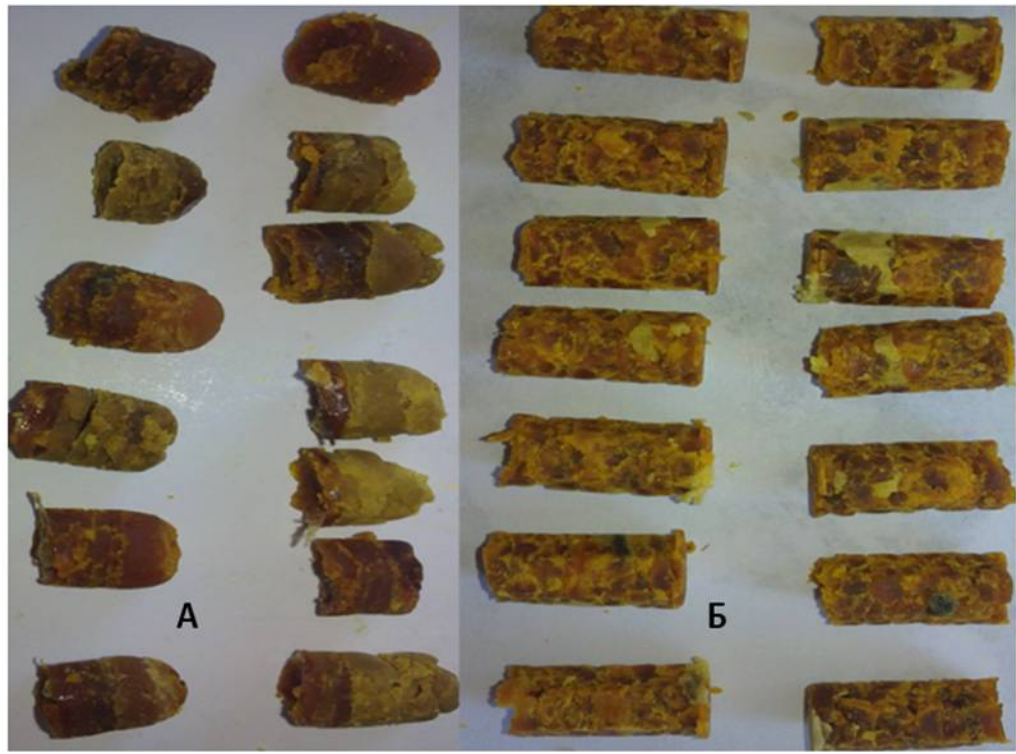

Figure 3 General view of bee bread pellets obtained in a primitive way (A) and newly developed (B). 


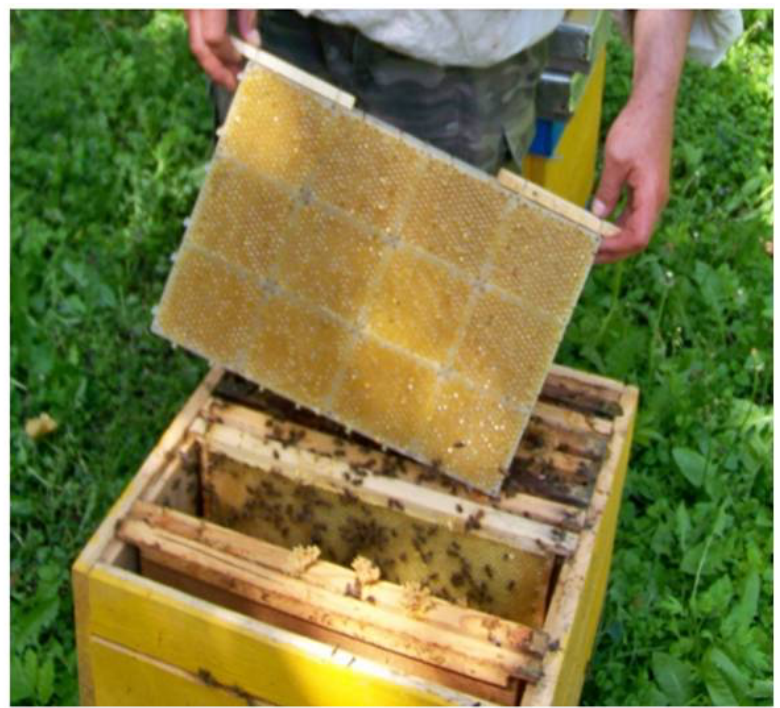

Figure 4 Placement of an artificial honeycomb with densely obstructed nets in the family.
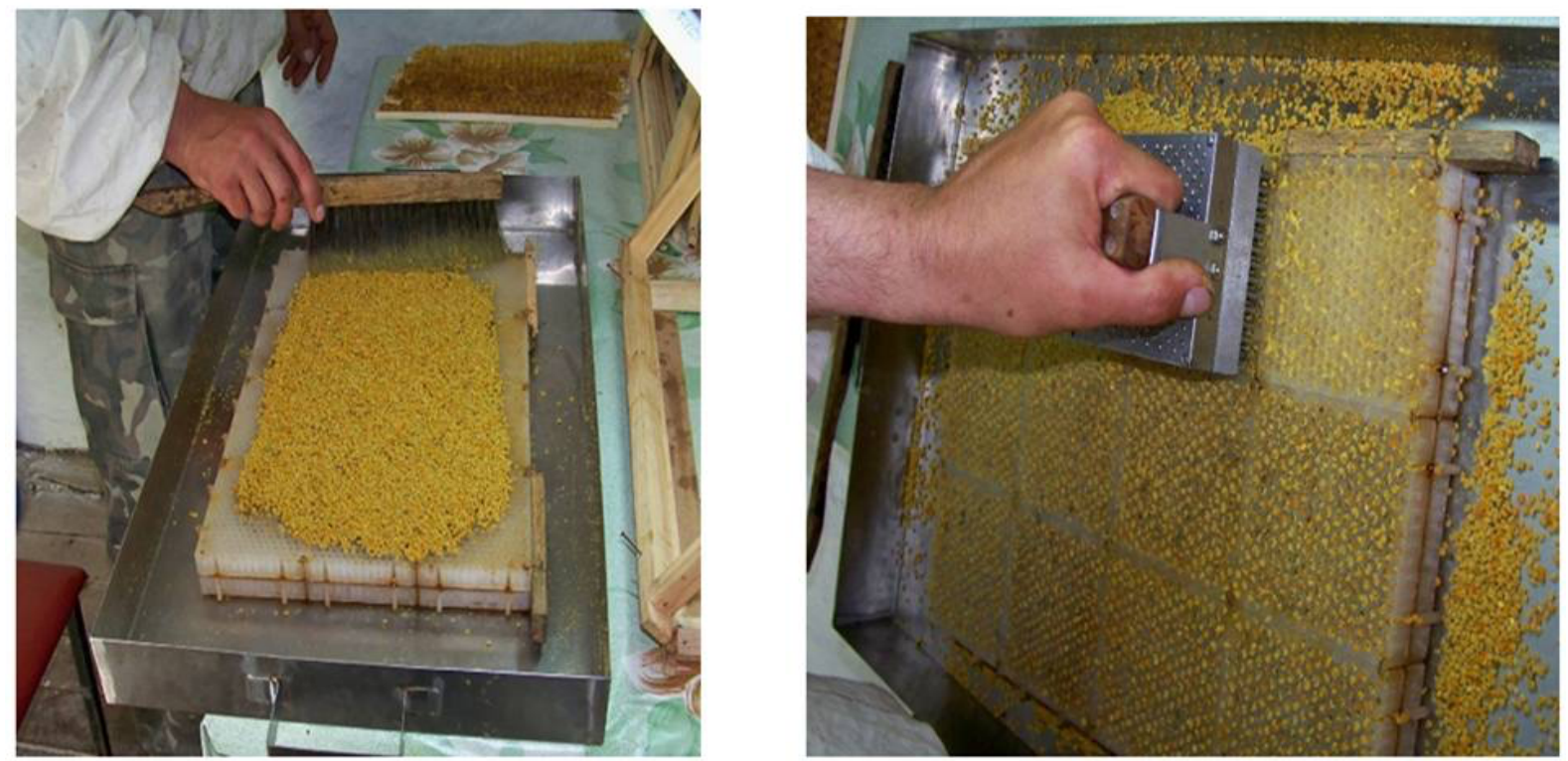

Figure 5 The process of filling the cell freshly pollen basket.

In research groups $3-6$ during a daily inspection of artificial honeycombs and the record of cells filled with protein food they appeared to be empty (Figure 4, Figure 5). The bees were shaken out of the honeycombs and $3-5$ pollen pellets were put into empty cells according to the investigation methods. All in all, this procedure has been done 4 times. Five honey bee colonies have been involved in these groups. These colonies have been chosen according to prototypes (Brovarskyi et al., 2007). The results of the records have been analyzed after the mathematical processing.

\section{Statistical Analysis}

For the characteristics of the files, we used the basic descriptors of variability: average, minimum measured value, maximum measured value, the coefficient of variation (\%). Data were analyzed with ANOVA test and differences between means compared through the TukeyKramer test $(\alpha=0.05)$. The degree of variability was determined by the coefficient of variation values. The given parameter is independent of the unit of the evaluated character.

\section{RESULTS AND DISCUSSION}

To stimulate honey bee colonies to store up protein food, lots of work has been done to form their nests. In every group, we have chosen honeycombs from every bee family. These honeycombs contain lots of cells filled with bee bread. Taking into account the fact that bees mostly consume bee bread while feeding slugs, we have chosen one honeycomb with sealed brood out of the nests. Instead of them, we have put the ones with unsealed brood. The honeycombs with sealed brood have been moved into the 
nests of bee colonies of the user group. The frames with slugs for experimental bee colonies have been chosen from them as well. According to our plan, the protein food deficit and a great number of the unsealed brood had to stimulate the bees to activate the process of collecting pollen.

According to the results of undertaken studies, the following things have been determined and brought to light (Table 1). In the methods that used only the preparation of artificial honeycombs (test group and research group 1,2) the bees passively domesticated the cells of the containers. The bees in the test group started to lay protein food into single cells only 4 days after the nests of the artificial honeycombs have been installed. During the $4^{\text {th }}$ record, the bees of the test group have involved only $0.004 \%$ of containers of the artificial honeycombs out of 5496 available for bee bread. Besides that, in the cells of the artificial honeycombs, the bees didn't grow brood and didn't create the reserves of carbohydrates.

The results that we got, having tested the artificial honeycomb in the test group, indicate that bees passively domesticate cells in the sections and it's impossible to use the artificial honeycomb effectively without involving the additional stimulation.

The results of testing artificial honeycombs in bee colonies of research groups 1 and 2 haven't been encouraging. During the first record in research group 1, in which honeycombs have been processed by wax, as well as in group 2, in which the cells have been processed by wax and honey syrup, the bees don't have to involve either of the cells to store food. In a day (record 2) we have seen the presence of protein food in separate cells of artificial honeycombs of research bee colonies 1 and 2. During the next two records, the intensity of forming protein reserves in these groups was almost of the same level. The bees of these colonies have involved the additional space for laying pollen pellet, but it referred only to at least 10 cells which constituted 0.004 and $0.003 \%$ from their overall amount of the honeycomb. It was noticed that in the process of forming bee bread reserves the bees not only filled the cells of the honeycomb with pollen pellet but also took food out of them.

Thus, using the artificial combs for making bee bread, even with extra processing of its elements with wax and honey syrup, does not encourage bees to lay and process protein food in cells.

The research of the etiology of bees with the help of different methods of putting dry and freshly harvested bee pollen pellets has been very encouraging. We have used dried pollen pellet in researches 3 and 4 .

As it appeared to be, the bees in the bee family in the $3^{\text {rd }}$ research group passively reacted to fill the cells with pollen pellet. The percentage of the cells filled with bee bread, regarding their overall amount on the artificial honeycombs, was from 0.007 to $0.4 \%$, on the condition that we refilled empty honeycombs with pollen pellet daily. Even when we processed pollen pellet with honey syrup (research 4) and thickened them, the bees insignificantly activated the process of laying the bee bread into the cells of artificial honeycombs. Using this method, we have identified a slight increase in the number of cells with bee bread located on artificial honeycombs $-0.2-1 \%$. It is important to underline that the bees enlarged the space for bee bread in these honeycombs with every following fill-up of the empty cells with pollen pellet. If to compare these results with the test group, the activity of bee families of this group in laying protein food was much higher.

Thus, the use of dry pollen pellet on the condition that it's put into the box of artificial honeycombs in small amounts doesn't stimulate bees to lay the bee bread intensively, even if the thickening and the processing of the food by honey syrup are done 4 times.

A completely different reaction of bees on laying the bee bread reserves took place when freshly harvested pollen pellet was used. In research group 5 the bees enlarged the space for forming protein food reserves even though $3-5$ pollen pellets were put into the cells of artificial honeycombs without being thickened. At the same time, if to look at the total amount of the cells of honeycombs in terms of quantity, these results would be still minor, but a sequence higher than in research 4 and other previous groups of bee colonies. For example, after the first fill-in of the fresh pollen pellet, the bees have put bee bread into the cells on the area that exceeded the research group 4 2.2 times. During the second record, the differences between these groups were 5.9 times, during the $3^{\text {rd }}$ record -3.6 , the $4^{\text {th }}-4.6$ times. If to compare it with the test group, the difference in data was highly probable $(p<0.01$; $p<0.001$ ). The freshly harvested pollen pellet may be more preferably for bees to thicken it in the cells because it contains plenty of was in it. Taking into account the results of these investigations, it can be inferred that the first thing that attracts bees to lay protein food reserves is, at first, the quality of pollen pellet. And the processing of the constitutive elements of the artificial honeycombs doesn't reinforce the bees' instinct of reprocessing the pollen into bee bread in cells. Besides that, as the bees use only fresh pollen pellet to stock bee bread, it is the most attractive thing for them to process protein food, unlike the dried pellets. It is not improbable that the dry pollen can be more difficult to yield to fermentation after-ripening of bee bread. We think that these processes are necessary to thoroughly research with the help of up-to-date biochemical, microbiological, physical, and other methods (Dranca, Ursachi and Oroian, 2020; Kubík et al., 2017; Kubík, Kažimírová and Brindza, 2020; Oroian, Ursachi and Dranca, 2020).

The most encouraging results were received in the $6^{\text {th }}$ research group. In this group after $3-5$ pollen pellets have been put into the cells and thickened, the artificial honeycombs were moved to the nests of bee colonies so that they could form protein food reserves. The research showed that during the first record the bees started to prepare the reserves of bee bread in $11.2 \%$ of cells of their total amount in the honeycombs. Compared to research 5, the bees of this group have enlarged the space for reprocessing pollen pellet into bee bread in honeycombs by 25.7 times.

After the next filling of the empty cells, the bees of this group slowed down the pace of forming protein food reserves. The number of cells with bee bread after the second record has increased by $3.2 \%$. During the $3^{\text {rd }}$ record, the number of cells filled with bee bread in the artificial combs exceeded the area of section 4. After the cells have been filled with pollen pellet for the $4^{\text {th }}$ time, the percentage of laying bee bread by workers was $81.7 \%$. 
Table 1 The effectiveness of putting the protein food by working bees under various conditions of preparation of artificial combs, $\mathrm{n}=5$.

\begin{tabular}{|c|c|c|c|c|c|c|c|c|}
\hline \multirow{3}{*}{ The way of comb preparation } & \multicolumn{8}{|c|}{$\begin{array}{c}\text { Domesticated cells among } 5496 \text { in the comb } \\
\text { The number of iterations }\end{array}$} \\
\hline & \multicolumn{2}{|c|}{$\mathbf{I}$} & \multicolumn{2}{|c|}{ II } & \multicolumn{2}{|l|}{ III } & \multicolumn{2}{|c|}{ IV } \\
\hline & $\mathbf{M} \pm \mathbf{S D}$ & $\%$ & $\mathbf{M} \pm \mathbf{S D}$ & $\%$ & $\mathbf{M} \pm \mathbf{S D}$ & $\%$ & $\mathbf{M} \pm \mathbf{S D}$ & $\%$ \\
\hline $\begin{array}{l}\text { Without processing the cell } \\
\text { (control) }\end{array}$ & - & - & - & - & - & - & $\begin{array}{c}0.2 \\
\pm 0.2\end{array}$ & 0.004 \\
\hline $\begin{array}{l}\text { The cells processed with wax } \\
(\operatorname{Exp} 1)\end{array}$ & - & - & $\begin{array}{c}0.2 \\
\pm 0.20\end{array}$ & 0.004 & $\begin{array}{c}0.8 \\
\pm 0.58\end{array}$ & 0.015 & $\begin{array}{c}0.2 \\
\pm 0.20\end{array}$ & 0.004 \\
\hline $\begin{array}{l}\text { The cells processed with wax } \\
\text { and honey syrup (Exp 2) }\end{array}$ & - & - & $\begin{array}{c}1.2 \\
\pm 0,58\end{array}$ & 0.022 & $\begin{array}{l}1.4 \\
\pm 0.60 \\
\quad *\end{array}$ & 0.025 & $\begin{array}{l}1.8 \\
\pm 0.37 \\
* *\end{array}$ & 0.033 \\
\hline \multicolumn{9}{|c|}{ In every iteration, the empty cells were filled with pollen pellet } \\
\hline $\begin{array}{l}3 \text {-4 dried pollen pellet put into } \\
\text { cells (Exp 3) }\end{array}$ & $\begin{array}{c}0.4 \\
\pm 0.24\end{array}$ & 0.007 & $\begin{array}{l}2.2 \\
\pm 0.58 \\
* *\end{array}$ & 0.400 & $\begin{array}{l}4.4 \\
\pm 0.93 \\
* * *\end{array}$ & 0.080 & $\begin{array}{l}10.8 \\
\pm 2.15 \\
* *\end{array}$ & 0.197 \\
\hline $\begin{array}{l}3 \text { - } 4 \text { dried pollen pellet put into } \\
\text { cells processed with honey syrup } \\
\text { and thickened (Exp } 4)\end{array}$ & $\begin{array}{l}11.0 \\
\pm 2.00 \\
* * *\end{array}$ & 0.200 & $\begin{array}{l}17.0 \\
\pm 2.43 \\
* * *\end{array}$ & 0.309 & $\begin{array}{l}54.2 \pm 7.66 \\
* * *\end{array}$ & 0.986 & $\begin{array}{l}52.2 \\
\pm 8.02 \\
* * *\end{array}$ & 0.950 \\
\hline $\begin{array}{l}3 \text { - } 4 \text { newly collected pollen pellet } \\
\text { put into cells (Exp 5) }\end{array}$ & $\begin{array}{c}24.0 \\
\pm 3.61 \\
* * *\end{array}$ & 0.437 & $\begin{array}{l}100.0 \\
\pm 4.64 \\
* * * *\end{array}$ & 1.820 & $\begin{array}{l}194.6 \\
\pm 25.76 \\
* * *\end{array}$ & 3.540 & $\begin{array}{c}239.2 \\
\pm 24.36 \\
* * * *\end{array}$ & 4.352 \\
\hline $\begin{array}{l}\text { 3-4 freshly collected pollen pellet } \\
\text { put into cells and thickened } \\
(\text { Exp 6) }\end{array}$ & $\begin{array}{c}617.0 \\
\pm 37.87 \\
* * * *\end{array}$ & 11.226 & $\begin{array}{c}636.6 \\
\pm 36.74 \\
* * * *\end{array}$ & 11.583 & $\begin{array}{c}976.6 \\
\pm 58.67 \\
* * * *\end{array}$ & 17.769 & $\begin{array}{c}4492.6 \\
\pm 362.02 \\
* * * *\end{array}$ & 81.743 \\
\hline
\end{tabular}

Notes: I $-1^{\text {st }}$ sampling; II $-2^{\text {nd }}$ sampling; III $-3^{\text {rd }}$ sampling; IV $-4^{\text {th }}$ sampling; mean - arithmetic mean; SD - standard error of the mean; ${ }^{*} p<0.1 ; * * p<0.02 ; * * * p<0.01 ; * * * * p<0.001$ in compare with control group; Exp 1-6 - experiment $1-6$.

Table 2 The effectiveness of different methods of getting bee bread with the help of an artificial honeycomb, $\mathrm{n}=5$.

\begin{tabular}{|c|c|c|c|c|c|c|}
\hline \multirow{3}{*}{ Index } & \multicolumn{6}{|c|}{ The ways of getting bee bread } \\
\hline & \multicolumn{2}{|c|}{$\begin{array}{c}\text { Test } \\
\text { (stimulation of bees to laying } \\
\text { bee bread by thickening small } \\
\text { portion of pollen pellet) }\end{array}$} & \multicolumn{2}{|c|}{$\begin{array}{c}\text { Research } 1 \\
\text { (single thickening of freshly } \\
\text { harvested pollen pellet of } 2 / 3 \\
\text { of the cells) }\end{array}$} & \multicolumn{2}{|c|}{$\begin{array}{l}\text { Research } 2 \\
\text { (single thickening of freshly } \\
\text { harvested pollen pellet of } 2 / 3 \\
\text { of the cells and processing } \\
\text { their surface with honey) }\end{array}$} \\
\hline & $\begin{array}{l}\text { the number of } \\
\text { cells filled } \\
\text { with bee } \\
\text { bread, item }\end{array}$ & $\begin{array}{l}\text { the amount of } \\
\text { bee bread } \\
\text { received from } \\
\text { one } \\
\text { honeycomb }(\mathrm{g})\end{array}$ & $\begin{array}{l}\text { the number } \\
\text { of cells } \\
\text { filled with } \\
\text { bee bread, } \\
\text { item. }\end{array}$ & $\begin{array}{l}\text { the amount of } \\
\text { bee bread } \\
\text { received from } \\
\text { one } \\
\text { honeycomb }(\mathrm{g})\end{array}$ & $\begin{array}{l}\text { the number } \\
\text { of cells filled } \\
\text { with bee } \\
\text { bread, item }\end{array}$ & $\begin{array}{l}\text { the amount of } \\
\text { bee bread } \\
\text { received from } \\
\text { one honeycomb } \\
(\mathrm{g})\end{array}$ \\
\hline $\boldsymbol{M} \pm \mathbf{S D}$ & $4400.2 \pm 371.06$ & $706.6 \pm 163.56$ & $4750.2 \pm 227.44$ & $1135.2 \pm 159.28$ & $4886.4 \pm 219.30$ & $1368.7 \pm 108.70^{*}$ \\
\hline $\min -\max$ & $3162-5139$ & $278.19-1205.06$ & $4181-5255$ & $711.82-1618.54$ & $4274-5357$ & $1073.54-1687.46$ \\
\hline $\mathrm{V} \%$ & 18.86 & 51.76 & 10.71 & 31.38 & 10.04 & 17.76 \\
\hline
\end{tabular}

Note: mean - arithmetic mean; SD - standard error of the mean; min, max - minimal and maximal measured values; $\mathrm{V}-$ coefficient of variation $\% ; * p<0.05$ compared to the test group.

Bees mainly laid the bee bread reserves starting from the bottom sections of the artificial honeycomb located closer to the back wall of the beehive. Besides that, the bees domesticated the cells and laid the bee bread better on those sides of the artificial honeycombs which were oriented to the central part of the nests of honey bee colonies, namely to the hive entrance block. The cells, which the bees laid bee bread into, could be identified according to several features. Examining the honeycombs in the cells, we found freshly harvested pollen pellet. The bees often dipped into them and the shiny spew appeared on the surface of protein food where the process of forming the pellets of the bee bread was finished.
In the process of forming protein food reserves, the bees managed not only to store bee bread but also consumed it even from those cells in which the upper layer of the pollen the bees processed by honey. However, the bees mostly consumed the protein food for the needs of their colonies from those cells which haven't been filled up with pollen pellet completely. As a rule, the bees did not consume the bee bread from the central sections and they ate bee bread in small amounts from the peripheral zones. Anderson et al. (2014) found that the bees significantly prefer to consume fresh pollen stored for $<72 \mathrm{~h}$. The tendency to eat fresh vs. older pollen stores may involve the strength or type 
of chemical signal emanating from stored pollen of variable age.

So, the workers on the artificial honeycombs to store protein food actively start to domesticate those cells which contain the first portions of the thickened freshly harvested pollen pellet. Processing of the cells by wax or honey syrup doesn't stimulate the bees to domesticate artificial honeycombs.

The sections of artificial honeycombs that were located closer to the back wall of the beehive were mostly the area for storing protein food. The bees gradually domesticate all the cells of the artificial honeycombs to process pollen pellet into bee bread. To make the bees lay and thicken pollen pellet it is necessary to fill the empty cells with freshly harvested pellets and thicken them not less than 4 times a day. It is not appropriate to use dried pollen pellet to stimulate the bees to lay bee bread into the cells of artificial honeycombs. The bees mostly take dried pellet out of the cells and unwillingly lay protein food reserves into them.

Taking into account that the most effective way of stimulating bees to store bee bread on the artificial honeycomb is the method of thickening of $3-5$ pellets of freshly chosen pollen pellet in the cells, it was used in further researches. Besides that, we were interested in researching the question of bees' reaction to protein food if $2 / 3^{\text {rd }}$ of the cells were filled with freshly harvested pollen pellets.

While researching the ethnology of bees that laid protein food it was found that they did not break pellets into pieces in the process of thickening pollen pellet. Thus, they do not add ferments into them. That is why we have decided to do additional researches with the help of artificial honeycombs. We have used two more methods in our research, except the method of stimulating bees, to store protein food by trampling down a small quantity of pollen pellet (test group). The first method was a single thickening of pollen pellet up to $2 / 3^{\text {rd }}$ of the height of the cells without processing it (research 1). The second method included the processing of the upper layer by honey (research 2). These ways of getting bee bread by using artificial honeycombs checked the method of stimulating the bees to store protein food by thickening a small amount of freshly harvested pollen pellet in the cells and the process has been repeated 4 times after that. To do this research we have used 3 bee colonies each of which had 5 bees. The honeycombs in the nest were placed in the same area as in the previous research. During this research, we have recorded the number of cells with bee bread and identified the total weight of the pollen pellet we have got after the honeycombs have been in the nests of bee colonies for 2 weeks. The data received during these researches can be found in Table 2 .

According to the intensity of laying protein food reserves into artificial honeycombs using different ways of stimulating bees to process pollen pellet into bee bread, it has been identified that the bee colonies of the test and research groups 1 and 2 had a different level of activity while doing this jobs. The common thing in the behavior of the bees in all the bee family groups was the thing that while laying bee bread and in the process of finishing its forming, the bees consumed protein food in small amounts. You could see that when the bees have finished processing upper levels of protein food by honey and started eating unripe bee bread the next day. The bees mostly consumed food from the cells of those sections which were located at the bottom of the sides of artificial honeycombs. The bees did not consume bee bread on the central sections of the honeycombs.

After 2 weeks, lots of sections that were located on the peripheral sides of artificial honeycombs had cells with a small amount of bee bread in them, and there were also the ones that appeared to be empty. The intensity of consuming protein food by bee colonies that belong to the same group was different. The bees of some colonies consumed less bee bread and some of them consumed more. The reason for such behavior of bees could not be identified. It is necessary to investigate these processes more thoroughly to solve this problem. It can be inferred that the intensity of consuming protein food depends on different factors. At first, it refers to the age of bee workers, their physiological state, the type and the amount of work that would be done, the quantity of unsealed brood in the nests of bee colonies, etc.

It has been proved that the bees of test and research groups used a different number of cells in artificial honeycombs to process pollen pellet into bee bread depending on the ways of stimulating bees to store protein food. Thus, at the end of the experiment, i.e. 14 days after the protein food reserves have been stored, we have found that $80.1 \%$ of the cells on artificial honeycombs were completely or partially filled by bee bread. Co-boundary data (Lim) of this group were between 3162 and 5139 cells. The input of protein food that varied according to the intensity of the process influenced the variation index, which was $18.9 \%$ in this group that shows the instability of this index because of the influence of different factors. In general, taking into account the fact that the bees have partially consumed protein food in the cells, single extraction of bee bread in terms of one artificial honeycomb in this group was $706.6 \mathrm{~g}$, with a minimum of $278.2 \mathrm{~g}$ and a maximum one of $1205.1 \mathrm{~g}(\mathrm{Lim})$, whereas the variation index was $51.76 \%$. It's necessary to mention that in this group, in which the bee workers did not take part in storing bee bread, protein food was consumed to the biggest extend. This indicates that bee workers use freshly harvested pollen pellet for their own needs at the time when it is actively produced. To decide, which the most attractive food for the bee family is pollen pellet or bee bread, it is necessary to thoroughly investigate the behavior and nutrition of bees.

In the first research group, where a single thickening of the artificial honeycombs section cells with freshly harvested pollen pellet was used, alongside the processing of bee bread, the bees consumed protein food in small amounts. This process was less active than in the test group, though. During the two weeks that were spent on keeping artificial honeycombs of bee colonies $86.4 \%$ of section cells were filled with bee bread. If to compare this method with the test group, the bees involved $7.9 \%$ cells more for storing bee bread. Because the bees were less active in consuming protein food from section cells, the amount of bee bread we got from one artificial honeycomb was $1135.2 \mathrm{~g}$ on average, which is $60.6 \%$ more than in the test group. However, if to calculate the number of cells involved and the amount of bee bread received, the difference between the test and the first research group was improbable $(p>0.1)$. 
While thickening pollen pellet in the cells of artificial honeycombs with processing food by honey (research 2) the bees worked on storing bee bread more actively. In this group, the percentage of the cells filled with bee bread was almost $90 \%$. Unlike the test group, the bees of the colonies of research group 2 used $11 \%$ more cells for storing protein food whereas in research group 1 the percentage was $2.9 \%$. However, alongside this, the consumption of protein food in this group was minimum, unlike in the methods previously used. This influenced the average amount of bee bread received in terms of one artificial honeycomb. Thus, according to the results of the records we got out of each artificial honeycomb, we got $1368.7 \mathrm{~g}$ in research group 2, which is $93.7 \%$ more than in the test group $(p<0.05)$ and was $20.6 \%$ higher than the index of research group 1 (the difference is improbable, $p>0.1)$. In research group 2 the co-boundary data were less (according to the number of the cells filled with bee bread as well as with the total amount of the pollen pellet received (Lim) if to compare other methods of preparing protein food to the processes of conservation.

By industrially maintaining bee-keeping, bee-keepers get not only honey from the bee colonies but other goods as well. It widens the range of apicultural products in the market and promotes enterprises' rise in profitability. At the same time, despite the increasing needs for separate kinds of apicultural goods, bee-bread in particular, their overall production level is very slight because of the lack of modern and effective technologies and equipment. So, to get bee-bread, bee-keepers use methods that are based on the destruction of wax combs (Lebedev and Kubrak, 1997; Nekrashevych, Kashyryn and Vynokurov, 2002; Psheslavskyi, 2010). Nowadays to get bee-bread, honeycombs made of artificial materials have been designed (Brovarskyi, Velychko and Kolesnik, 2013; Brovarskyi, Brindza and Velychko, 2015; Velychko, Brovarskyi and Brindza, 2011); the overall study of the morphology of the pellets (Velychko, Brovarskyi and Brindza, 2013), biochemical composition, and microbiology of this variety of the product have been also conducted (Brovarskyi et al., 2013; Brovarskyi and Velychko, 2014; Hryniewicka et al., 2016; Ivanišová et al., 2015; Kubík et al., 2017; Shevtsova et al., 2016). However, bees unwillingly domesticate the cells of such honeycombs, and the ways of regulating the processes of forming protein food reserves in them have not been designed at all. That is why the investigation of the behavior of bees and working out the ways of stimulating bee colonies to lay protein food are of vital importance from a theoretical as well as practical point of view.

To decrease the pressure of involving the bees in wax building activity, it needs to avoid problems of damaging frames (transporting bee colonies, pumping out honey, etc.), cut costs on buying empty honeycombs, effectively use the biological potential of bee colonies while getting a different kind of goods and improve their quality, prevent affection and spread of diseases, artificial materials for producing honeycombs are widely implemented nowadays. Among them are nest honeycombs, plastic empty honeycombs, plastic honey cells, honeycombs for getting even-aged brood in the artificial raising of queen bees, balls of queenbee cells made of polymer materials, etc. (Brovarskyi et al., 2014; Brovarskyi et al., 2017). To make bees domesticate artificial honeycombs or cells (balls of queenbee cells, Dombrovskyii honeycombs), different ways of activating this process are used (reducing the number of nests, processing the elements or cells of honeycombs by wax or carbohydrates, etc.) (Brovarskyi et al., 2013; Brovarskyi and Velychko, 2014; Brovarskyi, Velychko and Brindza, 2015; Brovarskyi et al., 2015). Nowadays, because of the lack of knowledge of honeybees' biology, there is a need for doing research on stimulating bee families to domesticate artificial honeycombs or their separate elements and design manufacturing technology of apicultural goods on their basis, bee-bread in particular. We have emphasized this particular problem in our investigations.

The aim and the task of the research were to investigate the ethnology of bees by different ways of stimulating them to form protein food reserves in artificial honeycombs. According to the set aim, the following things had to be done defining the effectiveness of laying bee bread by bees using different ways of preparing containers of artificial honeycombs; research the intensity of forming protein food reserves using different ways of stimulating bees.

\section{CONCLUSION}

The most effective way of stimulating bees to process pollen pellet into bee bread is its single thickening in artificial honeycombs with the following processing of the upper layer of food with honey. Such a method encourages the bees to form bee bread reserves and lessens their activity of consuming protein food from the cells of artificial honeycombs. It is likely that the processing of the thickened pollen pellet with honey oppresses the bees' necessity to consume protein food from the filled cells and redirects them to other honeycombs of the bee family nest which has areas filled with bee bread reserves.

\section{REFERENCES}

Abouda, Z., Zerdani, I., Kalalou, I., Faid, M., Ahami, M. T. 2011. The Antibacterial Activity of Moroccan Bee Bread and Bee-Pollen (Fresh and Dried) against Pathogenic Bacteria. Research Journal of Microbiology, vol. 6, no. 4, p. 376-384. https://doi.org/10.3923/jm.2011.376.384

Anđelković, B., Jevtić, G., Mladenović, M., Marković, J., Petrović, M., Nedić, N. 2012. Quality of pollen and honey bee bread collected in spring. Journal of Hygienic Engineering and Design, vol. 1, p. 275-277.

Anderson, K. E., Carroll, M. J., Sheehan, T., Mott, B. M., Maes, P., Corby-Harris, V. 2014. Hive-stored pollen of honey bees: Many lines of evidence are consistent with pollen preservation, not nutrient conversion. Molecular Ecology, vol. 23, no. 23, p. 5904-5917. https://doi.org/10.1111/mec.12966

Baltrušaityté, V., Venskutonis, P. R., Čeksteryté, V. 2007. Antibacterial activity of honey and bee bread of different origin against S. aurea and S. epidermis. Food Technology and Biotechnology, vol. 45, no. 2, p. 201-208.

Barajas, J., Cortes-Rodriguez, M., Rodríguez-Sandoval, E. 2012. Effect of temperature on the drying process of bee pollen from two zones of Colombia. Journal of Food Process Engineering, vol. 35 , no. 1, p. 134-148. https://doi.org/10.1111/j.1745-4530.2010.00577.x

Bleha, R., Shevtsová, T., Kružík, V., Brindza, J., Sinica, A. 2019a. Morphology, physicochemical properties and antioxidant capacity of bee pollens. Czech Journal of Food 


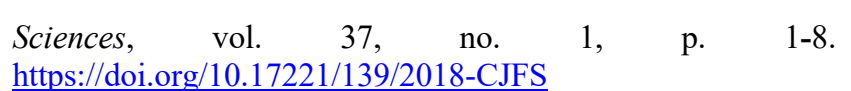

Bleha, R., Shevtsová, T., Kružík, V., Škorpilová, T., Saloň, I., Erban, V., Brindza, J., Brovarskyi, V., Sinica, A. 2019b. Bee breads from two regions of Eastern Ukraine: composition, physical properties and biological activities. Czech Journal of Food Sciences, vol. 37, no. 1, p. 9-20. https://doi.org/10.17221/201/2018-CJFS

Bogdanov, S. 2015. Pollen: Production, Nutrition and Health: A Review. Bee Product Sciences, vol. 10, p. 1-35.

Breed, M., Mizrahi, A., Lensky, Y. 1998. Bee Products: Properties, Applications, and Apitherapy. Bioscience, vol. 48, no. 9, p. 774-776. https://doi.org/10.2307/1313341

Brindza, J., Schubertova, Z., Velychko, S., Kreft I., Ivanišova E. 2015. The evaluation of bee bread quality. Scientific bulletin of the National University of Bioresources and Nature Management of Ukraine. Kyiv, vol. 223, p. 25-35.

Brovarskyi, V. D., Brindza, J., Kolesnik, A. J., Velychko, S. M. 2014. Bulletin of Zhytomyr National Agroecological University (Scientificaly-theoretical periodic), vol. 2, no. 44, p. 205-209.

Brovarskyi, V. D., Brindza, J., Kolesnik, A. J., Velychko, S. M. 2013. Biochemical processes in perga in various conditions of harvesting and storage. Materials of the Interdisciplinary Scientific and Practical. Conference "Water and Human Health", Uzhorod, p. 232-235.

Brovarskyi, V. D., Brindza, J., Kolesnik, A. J., Velychko, S. M., Grygorieva, O. V. 2007. Amino acid storage of perga beyond high temperature periods in drying. Materials of the First International Scientific Conference "Unconventional, new and forgotten plants: scientific and practical aspects of cultivation". Kyiv, p. 370-374.

Brovarskyi, V. D., Brindza, J., Otchenashko, V. V., Povoznikov, M. H., Adamchuk, L. O. 2017. Experimental methods in beekeeping, Kyiv, Vydavnychyi dim «Vinnichenko», $166 \mathrm{p}$.

Brovarskyi, V. D., Brindza, J., Velychko, S. M. 2015. Industrial technology of bee-bread production (methodical recommendations). Kyiv, Ukraine : NULES of Ukraine editorial office, $22 \mathrm{p}$.

Brovarskyi, V. D., Brindza, J., Velychko, S. M., Adamchuk, L. O. 2016. Technological aspects of the production of bee bread like a biological active product. Collected Works of the $I X$ International Interdisciplinary Scientific and ractical Conference "Modern Aspects of Preserving Human Health". Uzhorod, Ukraine : Uzhorod National University, 1. ed. 388 p. ISBN 978-617-673-446-8. p. 66-68.

Brovarskyi, V. D., Brindza, J.,Velychko, S. M., Adamchuk, L. O., Kolesnik, A. J. 2015. New technologies for taking bee bread. Agrarian Science, Education, Production: European Experience for Ukraine: Materials of International scientificpractical conference, November 17-18. (Zhitomir: ZNAEU). Zhitomir, p. 280-286.

Brovarskyi, V. D., Velychko, S. M. 2014. Biochemical storage of perga from meadows the Forest-steppe of Ukraine. Materials of the International scientific and practical correspondence "Fruit, medicinal, technical, ornamental herbs: actual problems of introduction, biology, selection, cultivation technology". Kyiv, Ukraine, p. 55-58.

Brovarskyi, V. D., Velychko, S. M., Brindza, J. 2015. Ethology of Bees in the Formation of Protein Feed Stocks. Agrobiodiversity for improving nutrition, health and life quality, Nitra, Part I, p. 65-68. ISBN 978-80-552-1394-1.

Brovarskyi, V. D., Velychko, S. M., Kolesnik, A. J. 2013. Morphological features of perga. National Library of Ukraine of Vernackii. vol. 37, no. 1. Available at: http://www.nbuv.gov.ua/e-journals/Nd/2013_1/13bvd.pdf/

Capcarová, M., Kalafová, A., Schwarzová, M., Schneidgenová, M., Šoltésová Prnová, M., Švík, K., Slovák, L., Kišška, P., Kováčik, A., Brindza, J. 2020. Consumption of bee bread influences glycaemia and development of diabetes in obese spontaneous diabetic rats. Biologia, vol. 75, p. 705-711. https://doi.org/10.2478/s11756-019-00337-5

Čeksteryte, V., Račys, J., Kaškonienė, V., Venskutonis, P. R. 2008. Fatty acid composition in bee bread. Biologija, vol. 54, no. 4, p. 253-257. https://doi.org/10.2478/v10054-008-0052-2

DeGrandi-Hoffman, G., Chen, Y., Simonds, R. 2013. The Effects of Pesticides on Queen Rearing and Virus Titers in Honey Bees (Apis mellifera L.). Insects, vol. 4, no. 1, p. 71-89. https://doi.org/10.3390/insects4010071

Deveza, M. V., Keller, K. M., Lorenzon, M. C. A., Nunes, L. M. T., Sales, É. O., Barth, O. M. 2015. Mycotoxicological and palynological profiles of commercial brands of dried bee pollen. Brazilian Journal of Microbiology, vol. 46, no. 4, p. 1171-1176. https://doi.org/10.1590/S1517-838246420140316

Didaras, N. A., Karatasou, K., Dimitriou, T. G., Amoutzias, G. D., Mossialos, D. 2020. Antimicrobial Activity of BeeCollected Pollen and Beebread: State of the Art and Future Perspectives. Antibiotics, vol. 9, no. 11, 29 p. https://doi.org/10.3390/antibiotics9110811

Dranca, F., Ursachi, F., Oroian, M. 2020. Bee Bread: Physicochemical Characteriztion and Phenolic Content Extraction Optimization. Foods, vol. 9, no. 10, 14 p. https://doi.org/10.3390/foods9101358

Fatrcová-Šramková, K., Nôžková, J., Ostrovský, R. 2010. Nutričné vlastnosti včelieho pel'u (Nutritional properties of bee pollen). Potravinárstvo, vol. 4, p. 24-32. (In Slovak) Available at:

https://www.potravinarstvo.com/dokumenty/mc_februar_201 0/pdf/1/Fatrcova-Sramkova.pdf

Fuenmayor, B. C., Zuluaga, D. C., Díaz, M. C., de Quicazán, C. M., Cosio, M., Mannino, S. 2014. Evaluation of the physicochemical and functional properties of Colombian bee pollen. Revista MVZ Córdoba, vol. 19, no. 1, p. 4003-4014. https://doi.org/10.21897/rmvz.120

Grygorieva, O., Klymenko, S., Vinogradova, Y., Motyleva, S., Gurnenko, I., Piórecki, N., Brindza, J. 2018. Study of Morphological Characteristics of Pollen Grains of Aronia mitschurinii A.K. Skvortsov \& Maitul. Agrobiodiversity for Improving Nutrition, Health and Life Quality, no. 2, p. 49-56. https://doi.org/10.15414/agrobiodiversity.2018.2585$\underline{8246.049-056}$

Haščík, P., Pavelková, A., Kalafová, A., Capcarová, M., Čuboň, J., Bučko, O., Kačániová, M., Hanusová, E., Tkáčová, J., Bobko, M. 2020. Chemical composition of muscle after bee bread application in the nutrition of Japanese quails. Journal of Microbiology, Biotechnology and Food Sciences, vol. 9, no. 4, p. 831-835. https://doi.org/10.15414/jmbfs.2020.9.4.831-835

Horčinová Sedláčková, V., Grygorieva, O. V., Gurnenko, I., Vergun, O. M. 2020b. Diversity of Sambucus nigra pollen within Slovakia in selected morphological characters by SEM study. Biosystems Diversity, vol. 28, no. 4, p. 399-404. https://doi.org/10.15421/012051

Horčinová Sedláčková, V., Grygorieva, O., Brindza, J. 2020a. Amino acid compositions of staminate catkins, pollen and honey from Castanea sativa Mill. Fundamental and applied aspects of plant introduction in the content of global environmental change. Kyiv, Ukraine : Gryshko National Botanical Garden, 1st ed. p. 323-326. ISBN 978-617-7910-762. 
Hryniewicka, M., Karpinska, A., Kijewska, M., Turkowicz, M. J., Karpinska, J. 2016. LC/MS/MS analysis of $\alpha$-tocopherol and coenzyme $\mathrm{Q}_{10}$ content in lyophilized royal jelly, beebread and drone homogenate. Journal of Mass Spectrometry, vol. 51, no. 11, p. 1023-1029. https://doi.org/10.1002/jms.3821

Hudz, N., Ivanova, R., Brindza, J., Grygorieva, O., Schubertová, Z., Ivanišová, E. 2017a. Approaches to the determination of antioxidant activity of extracts from bee bread and safflowers leaves and flowers. Potravinarstvo Slovak Journal of Food Sciences, vol. 11, no. 1, p. 480-488. https://doi.org/10.5219/786

Hudz, N., Korzeniowska, K., Wieczorek, P. P., Schubertová, Z., Brindza, J., Ivanišová, E. 2017b. Approaches to the Identification and Assay of Flavonoids in Bee Bread Extracts by Spectrophotometric Method. Agrobiodiversity for Improving Nutrition, Health and Life Quality, no. 1, p. 168173. https://doi.org/10.15414/agrobiodiversity.2017.2585$\underline{8246.168-173}$

Ivanišová, E., Kačániová, M., Frančáková, H., Petrová, J., Hutková, J., Brovarskyi, V., Velychko, S., Adamchuk, L., Schubertová, Z., Musilová, J. 2015. Bee bread - perspective source of bioactive compounds for future. Potravinarstvo Slovak Journal of Food Sciences, vol. 9, no. 1, p. 592-598. https://doi.org/10.5219/558

Komosińska-Vassev, K., Olczyk, P., Kaźmierczak, J., Mencner, L., Olczyk, K. 2015. Bee Pollen: Chemical Composition and Therapeutic Application. Evidence-based Complementary and Alternative Medicine, vol. 2015, 6 p. https://doi.org/10.1155/2015/297425

Krell, R. 1996. Value-added products from beekeeping. FAO Food and Agriculture in Nitra Organization of the United Nations Roma, 409 p.

Kubík, L., Brindza, J., Brovarskyi, V., Velychko, S. 2017. Perga pri dejstvu pritisnog opterećenja (Bee-bread under compressive loading hinge under the action of pressure load). Journal on Processing and Energy in Agriculture, vol. 21, no. 1 , p. 23-26. (In Ukrainian) https://doi.org/10.5937/JPEA1701023K

Kubík, L., Kažimírová, V., Brindza, J. 2020. Mechaničke osobine heljdine perge (Mechanical properties of buckwheat perga). Journal of Processing and Energy in Agriculture, vol. 24, no. 1, p. 39-42. (In Ukrainian) https://doi.org/10.5937/jpea24-25557

Lebedev, V. I., Kubrak, L. I. 1997. Collection of scientific works "Apitherapy today". Rybnoe, p. 51-53.

Lokutova, O. 2015. Determination of botanical origin of pollen load and its amino acid composition. Agrobiodiversity for Improving Nutrition, Health and Life Quality, p. 431-437. ISBN 978-80-552-1394-1.

Mizrahi, A., Lensky, Y. 1997. Bee products: properties, applications, and apitherapy. New York, USA : Springer, p. 93-101. ISBN 978-03-064-5502-5.

Motyleva, S. M., Brindza, J., Šimková, J., Horčinová Sedláčková, V. 2018b. Comparative Study of Morphometric Characteristics and Mineral Composition of Pollen Malus domestica Borkh. Agrobiodiversity for Improving Nutrition, Health and Life Quality, no. 2, p. 285-291. https://doi.org/10.15414/agrobiodiversity.2018.25858246.285-291

Motyleva, S. M., Gruner, L., Semenova, L. 2018a. The Morphology of Pollen Grains of Some Cultivars Rubus fruticosus L. Agrobiodiversity for Improving Nutrition, Health and Life Quality, no. 2, 6 p. https://doi.org/10.15414/agrobiodiversity.2018.2585$\underline{8246.001-006}$
Nagai, T., Nagashima, T., Myoda, T., Inoue, R. 2004. Preparation and functional properties of extracts from bee bread. Food/Nahrung, vol. 48, no. 3, p. 226-229. https://doi.org/10.1002/food.200300421

Nekrashevych, V. F., Kashyryn, D. E., Vynokurov, C. B. 2002. Extraction of bee-bread from honey combs. Beekeeping, no. 5 , p. 48-50.

Nikolaieva, N., Kačániová, M., Collado González, J., Grygorieva, O., Nôžková, J. 2019. Determination of microbiological contamination, antibacterial and antioxidant activities of natural plant hazelnut (Corylus avellana L.) pollen. Journal of Environmental Science and Health, Part B, vol. 54, no. 6, p. 525-532. https://doi.org/10.1080/03601234.2019.1603756

Oroian, M., Ursachi, F., Dranca, F. 2020. Influence of ultrasonic amplitude, temperature, time and solvent concentration on bioactive compounds extraction from propolis. Ultrasonic Sonochemistry, vol. 64. https://doi.org/10.1016/j.ultsonch.2020.105021

Psheslavskyi, A. 2010. Bee-bread. Kyiv, Ukraine : Vydavnytstvo Pasika, $80 \mathrm{p}$.

Shevtsova, T., Bleha, R., Kyselka, J., Synytsya, A., Brindza, J., Brovarskyi, V., Filip, V. 2016. Bee bread as food product: microbial background, microscopic and spectroscopic evaluation. XLVI CONTRIBUTION WORDS. Symposium on New Directions for Food Production and Evaluation (23-25 May 2016, Skalský Dvůr). Institute of Food and Nutrition Analysis, Institute of Chemical Technology, Prague. Extractive Institute of Food. p. 113-118.

Urcan, A., Criste, A., Dezmirean, D. S., Bobis, O., Mărghitaş, L., Mărgăoan, R., Hrinca, A. 2018. Antimicrobial activity of bee bread extracts against different bacterial strains. Bulletin of University of Agriculture Sciences and Veterinary Medicine (Cluj-Napoca Animal Science and Biotechnologies), vol. 75 , no. 2, 85 p. https://doi.org/10.15835/buasvmcnasb:2018.0004

Velychko, S. M., Brovarskyi, V. D., Brindza, J. 2011. Artificial honey comb fór bee-bread production. Patent on "korysnu model" no. 5417.

Velychko, S., Brovarskyi, V., Brindza, J. 2013. Rationale Technology for Obtaining of Bee-bread. XXXXIII International Apicultural Congress Apimondia. 29 September - 4 Oktober 2013, Kyiv, Ukraine, p. 322-323.

Vergun, O., Horčinová Sedláčková, V., Schubertová, Z., Šimková, J., Brindza, J. 2019. Biochemical composition of bee pollen and inflorescence of Brassica napus L. var. napus. Agrobiodiversity for improve the nutrition, health and quality of human and bees life. Nitra, Slovak republic : Slovenská pol'nohospodárska univerzita, 64 p. ISBN 978-80-552-2037-6. Yildiz, O., Can, Z., Saral, Ö., Yuluğ, E., Özturk, F., Aliyazicioğlu, R., Canpolat, S., Kolayli, S. 2013. Hepatoprotective Potential of Chestnut Bee Pollen on Carbon Tetrachloride-Induced Hepatic Damages in Rats. EvidenceBased Complementary and Alternative Medicine, vol. 2013, 9 p. https://doi.org/10.1155/2013/461478

Zuluaga, C. M., Serrato, J. M., Quicazan, M. C. 2015. Chemical, Nutritional and Bioactive Characterization of Colombian Bee-Bread. Chemical Engineering Transactions, vol. 43, p. 175-180. Available at: http://www.aidic.it/cet/15/43/030.pdf

\section{Funds:}

The publication was realized within theproject ITEBIOITMS 26220220115. 


\section{Acknowledgments:}

The publication was created in cooperation with the international network AgroBioNet in the implementation of the international project in the program "Agrobiodiversity for Improving Nutrition, Health and Quality of Life" and in the project ITEBIO-ITMS 26220220115.

\section{Conflict of Interest:}

Experiments with hives were carried out on hives owned by the author of the publication, Mr Serhii Velychko, who is an officially registered beekeeper in the National Organization of Beekeepers of Ukraine.

\section{Ethical Statement:}

Proposed experiment on hives was discussed by the Ethics Committee of the Ministry of Agriculture of Ukraine without comment, because he did not use in the experiments any techniques or synthetic chemicals that caused health problems or death of bees.

\section{Contact Address:}

Serhii Velychko, National University of Life and Environmental Sciences of Ukraine, Department of beekeeping, Heroiv Oborony St, 15, Kyiv, Ukraine, Tel.: +380503041661 ,

E-mail: svelichko.bee@rambler.ru

ORCID: https://orcid.org/0000-0003-0233-9094

Valeryii Brovarskyi, National University of Life and Environmental Sciences of Ukraine, Department of beekeeping, Heroiv Oborony St, 15, Kyiv, Ukraine 03041, Tel.: +380665092859,

E-mail: brovarskyiv@gmail.com

ORCID: https://orcid.org/0000-0001-5922-973X

*Ján Brindza, Slovak University of Agriculture in Nitra, Faculty of Agrobiology and Food Resources, Institute of Biodiversity Conservation and Biosafety, Trieda Andreja Hlinku 2, 94976 Nitra, Slovakia. Tel.: +421376414787, E-mail: jan.brindza@uniag.sk

ORCID: https://orcid.org/0000-0001-8388-8233

Corresponding author: * 